ORGINAL ARTICLE

\title{
Effect of leaching and particles size in some properties of particleboards produced with Dendrocalamus asper (Schult. \& Schult. f.) Backer ex K. Heyne
}

\author{
Efeito da lixiviação e tamanho das partículas em algumas propriedades de \\ painéis de partículas produzidos com Dendrocalamus asper (Schult. \& Schult. F.) \\ Backer ex K. Heyne \\ Flávia Maria Silva Brito ${ }^{1}$ (D), Geraldo Bortoletto Júnior ${ }^{1}$ (D) , Juarez Benigno Paes $^{2}$ (D) \\ ${ }^{1}$ Escola Superior de Agricultura "Luiz de Queiroz" - ESALQ, Universidade de São Paulo - USP, Piracicaba, SP, Brasil \\ ${ }^{2}$ Universidade Federal do Espírito Santo - UFES, Jerônimo Monteiro, ES, Brasil.
}

\begin{abstract}
How to cite: Brito, F. M. S., Bortoletto, G., \& Paes, J. B. (2021). Effect of leaching and particles size in some properties of particleboards produced with Dendrocalamusasper (Schult. \& Schult. f.) Backer ex K. Heyne. Scientia Forestalis, 49(131), e3356. https://doi.org/10.18671/scifor.v49n131.15
\end{abstract}

\begin{abstract}
The aim of this work was to quantify the effect of size and hot-water leaching of Dendrocalamus asper (Schult. \& Schult. f.) Backer ex K. Heyne particles on some properties of particleboards. Trametes versicolor (white rot), Brunneoporus malicola $\approx$ Gloeophyllum trabeum and Postia placenta $\approx$ Rhodonia placenta (brown rot) were used in the biological resistance test. Water and ethylene glycol were used for wettability. The treatment of the particles reduced the content of extractives and ash. The panels made up of particles with a particle size of $0.85 \mathrm{~mm}$ (control) showed no improvement in biological resistance for the fungi $B$. malicola and $T$. versicolor. The treated particleboards were classified as moderately resistant to the tested fungi. There were no significant differences between treatments in the initial and final contact angles for ethylene glycol. For the contact angles obtained with water in the initial time, there was interaction between the factors tested and for the final angles obtained with water; there was significance of the isolated factors.
\end{abstract}

Keywords: Wettability; Leaching in hot-water; Rot-fungi test.

\section{Resumo}

O objetivo deste trabalho foi avaliar o efeito do tamanho e da lixiviação em água quente das partículas de Dendrocalamus asper (Schult. \& Schult. F.) Backer ex K. Heyne em algumas propriedades de painéis de partículas. Trametes versicolor (podridão branca), Brunneoporus malicola $\approx$ Gloeophyllum trabeum e Postia placenta $\approx$ Rhodonia placenta (podridão parda) foram utilizados no teste de resistência biológica. Água e etileno glicol foram usados para a molhabilidade. O tratamento das partículas reduziu o teor de extrativos e cinzas. Os painéis constituídos por partículas de granulometria 0,85 mm (controle) não tratadas evidenciaram melhorias na resistência biológica para os fungos $B$. malicola e $T$. versicolor. Os painéis de partículas tratadas foram classificados como moderadamente resistentes aos fungos testados. Não foram observadas diferenças significativas entre os tratamentos nos ângulos de contato inicial e final obtidos com etileno glicol. Para os ângulos de contato obtidos com água no tempo inicial houve interação entre os fatores testados e significância dos fatores isolados para os ângulos finais obtidos com água.

Palavras-chave: Ângulo de contato; Lixiviação em água quente; Testes com fungos apodrecedores.

Financial support: Nothing to declare.

Conflict of interest: Nothing to declare.

Corresponding author: faengflorestal@gmail.com

Received: 2 May 2019.

Accepted: 27 January 2021.

Editor: Paulo Henrique Müller Silva.

(c) (i) This is an Open Access article distributed under the terms of the Creative Commons Attribution License, which permits unrestricted use,

c) distribution, and reproduction in any medium, provided the original work is properly cited. 


\section{INTRODUCTION}

Bamboo is a material whose mechanical properties indicate a good potential to be exploited for engineering (Lima Júnior \& Dias, 2001). It is a renewable and fast-growing resource with high productivity by area, low cost and diversified use, in addition to being considered an excellent carbon sequestration agent (Calegari et al., 2007). It can be used in practically all spheres of human activities, from the roughest applications, like the use of thatch in natura, as well as the most advanced, which require complex industrial processes. Bamboo can be used in almost all sectors where commonly wood is used, such as: furniture, civil construction, civil construction applications, glued laminated bamboo, pulp and paper and food (Nascimento, 2020), handicrafts, musical instruments, charcoal and various utensils.

Currently, 258 species of native bamboo are known in Brazil, distributed in two tribes, Olyreae and Bambuseae, and 35 genera. Endemism in Brazil is high: there are 12 genera and 175 species (Filgueiras \& Viana, 2017). Its exploration, however, is still small in view of its versatility. In other countries, such as Colombia and Ecuador, bamboo is used as a popular building material not only for civil construction, but also in the creation of agro-industries, which promote rural development (Guilherme et al., 2017).

Dendrocalamus asper (Schult) Backer ex Hayne is a species of bamboo that was chosen due to its physical and mechanical properties and availability in the area of experimentation of the present work in the State of São Paulo - Brazil. It is native to Southeast Asia and was probably brought to the country by Portuguese colonizers. It has large clumps, up to $30 \mathrm{~m}$ high and the stem diameter at the base can reach more than $30 \mathrm{~cm}$ in clumps grown in Brazil (Tombolato et al., 2012). In Brazil, this species is widely used for structures of all sizes and in the manufacture of glued laminated bamboo products (Tombolato et al., 2012), due to its good resistance and absorbing compression very well, so it is very useful for construction in general.

As a disadvantage is the low resistance of the bamboo to the attack of xylophagous organisms, which varies according to the species; age; the contents of carbohydrates and moisture; density; weather conditions and form of utilization (Kumar et al., 1994). Therefore, treatments are required for increasing the lifespan of the culms. Most treatments aim to increase resistance to the attack of bamboo powder post borers, such as Dinoderus minutus (Fabricius) which are attracted by the starch present in the culms (Oliveira et al., 2002).

Many researches have already been carried out using bamboo associated or not with other lignocellulosic materials for the panel production such as: Dinhane et al. (2015), José \& Beraldo (2010), Arruda et al. (2011), Abdulkareem \& Adeniyi (2017) Marinho et al. (2013), Almeida et al. (2017), Melo et al. (2015a), Zaia et al. (2015), Nurhazwani et al. (2016), Morais et al. (2018), Bazzetto et al. (2019).

For the production of particleboards, Ferreira (2013) mentions that the particle geometry is an important parameter to be controlled, for making quality products. The geometry can determine certain characteristics of the panel, mainly the mechanical ones (Moslemi, 1974; Haselein et al., 2002; Iwakiri, 2005). Some important characteristics of the particles are highlighted, such as the slenderness index, flatness ratio and specific surface area directly related to geometry (Maloney, 1977; Iwakiri, 2005; Razera, 2006).

Changes in the volume of the mattress result from the use of different types and geometry of particles. The smaller the volume of the mattress, the smaller the receiving area of the emulsion compounds, such as adhesive, paraffin and water, as a result, the greater the losses (Calegari et al., 2004).

Another important factor in the production of particleboards is extractives. Their main effects are related to the reduction of hygroscopicity and permeability of wood (Cruz et al., 2006). They can be extracted with water and organic solvents (Oliveira et al., 2005). Wood with high extractive content is difficult to bond resulting in low resistance of the adhesion between the particles (Marra, 1992).

Some research has already been carried out with the aim of treating particles. Iwakiri \& Prata (2008) conducted a study with the aim of evaluating the potential use of Eucalyptus grandis and $E$. dunnii wood in the production of cement-wood panels and carried out treatments with 
the particles in cold water and hot water. Sá et al. (2012) tested three methods for extracting particulate chemicals: (a) immersing the particles in cold water for 24 hours; (b) immersion in hot water for 6 hours; and immersion in 1\% sodium hydroxide solution $(\mathrm{NaOH})$ for 2 hours. Amiandamhen \& Izekor (2013) found positive effects of the pre-treatment of wood particles from the gmelina tree with hot water and calcium chloride for a period of 24 hours on the mechanical properties of the panels. Iwakiri et al. (2017) worked with treated Hevea brasiliensis particles for the production of panels and concluded that physical and mechanical tests indicated better results for panels produced with particles treated in hot water.

There are reports in the literature about experiments related to the biological resistance of particleboards made of wood particles that may or may not be associated with other lignocellulosic materials. Among these are: Melo \& Del Menezzi (2010); Stangerlin et al. (2011); Belini et al. (2014); Gonçalves et al. (2014); Melo et al. (2015b); Yingprasert et al. (2015); Teixeira et al. (2009) and Reinprecht et al. (2018). Work related to the wettability of particleboards is scarce in the literature.

Wettability is defined as a condition of a surface that determines how quickly a liquid will get wet and spread on the surface, or whether it will be repelled and will not spread on the surface. There are, however, a few works related to the wettability of particleboard in literature. Among these, the following stand out: Chong \& Yang (2010); Baharoğlu et al. (2012) and Vital et al. (2014).

The aim of this work was to evaluate the effect of size and hot-water leaching of Dendrocalamus asper (Schult. \& Schult. f.) Backer ex K. Heyne particles on some properties of particleboards.

\section{MATERIALS AND METHODS}

\section{Material collection}

The bamboo culms (Dendrocalamus asper (Schult. \& Schult. f.) Backer ex K. Heyne) were collected at the Unit of Research and Development of the Agronomic Institute of Campinas in Tatuí, São Paulo state, Brazil. Adult culms (over 3 years old) were selected according to the presence of white spots and branching, which indicated their maturity.

The material was transformed into splinters according to the recommendations of Brito et al. (2018), and further into chips by a band saw. The chips were air-dried on a canvas in the courtyard ( $\pm 18 \%$ moisture content) and oven-dried with air-forced circulation at $70 \pm 2^{\circ} \mathrm{C}$ for 3 hours until $10 \%$. They were transformed into particles in a Thomas Wiley ${ }^{\circledR}$ mill with a sieve of $4.00 \mathrm{~mm}$. A set of sieves $(2.00,0.85$ and $0.50 \mathrm{~mm}$ ) was used for the classification; and the particleboards were produced with the fractions retained in the $0.85 \mathrm{~mm}$ and $0.50 \mathrm{~mm}$ sieves.

\section{Leaching in hot water}

Part of the particles were leached in hot water for the removal of soluble materials (extractives, sugars and metallic ions) that might hamper bonding. This step was carried out in a structure with $630 \times 300 \times 830 \mathrm{~mm}$ (width $\times$ height $\times$ length) made of iron bars ( $8 \mathrm{~mm}$ of diameter), internally coated with a double layer of plastic netting.

The leaching process was carried out at $70 \pm 5^{\circ} \mathrm{C}$ for 2 hours in a container of $1.200 \times 700 \times 1.500 \mathrm{~mm}$ (width $\times$ height $\times$ length). Finally, the particles were washed in running water and dried until a $3-4 \%$ moisture content.

Four treatments were investigated in this work, derived from the combination of the factors particles size $(0.50 \mathrm{~mm}$ and $0.85 \mathrm{~mm})$ and by leaching in hot water (untreated and leached).

\section{Chemical analysis of the particles}

Particles treated by immersion in hot water and control particles were analyzed separately. They were transformed into sawdust and sieved, and the 60-mesh portion was 
used. The content of each chemical component was calculated on an oven-dry base. Four replications were carried out for every analysis.

The determination of insoluble and soluble lignin was carried out according to the Technical Association of the Pulp and Paper Industry- TAPPI 222 cm-02 (Technical Association of the Pulp and Paper Industry, 2002a). The total lignin was the sum of the contents. TAPPI 207 cm - 99 (Technical Association of the Pulp and Paper Industry, 1999) method was used for the determination of the extractives' solubility in hot water. The total extractives content was determined according to the method TAPPI $204 \mathrm{~cm}-97$ (Technical Association of the Pulp and Paper Industry, 1997), using cyclo-hexane: ethanol (2:1; v:v), followed by extraction in hot water. TAPPI 211 om - 02 (Technical Association of the Pulp and Paper Industry, 2002b) method was used for the ash content. The holocellulose content was calculated as follows [\% holocellulose $=100-$ (total extractives + total lignin + ash $)$.

\section{Particleboards production}

The panels were produced with $0.65 \mathrm{~g} . \mathrm{cm}^{-3}$ target density and a nominal thickness of $15.70 \mathrm{~mm}$. Urea-formaldehyde resin was applied in a proportion of $10 \%$ of the oven-dried mass of particles, which had $64.16 \%$ of solid content and $1.27 \mathrm{~g} . \mathrm{cm}^{-3}$ density; a pH of 7.88; $121^{\circ} \mathrm{C}$ for 8.19 minutes, and a viscosity of $640 \mathrm{CP}$ at $25^{\circ} \mathrm{C}$. Ammonium sulfate $(5.0 \%$ of solid content) was the catalyst. The adhesive was sprayed on the particles in a slasher of warp $(12 \mathrm{rpm})$ for $5 \mathrm{~min}$. After this process, the paraffin emulsion (1.0\% of solid content) was sprayed separately on the particles (5 min - $12 \mathrm{rpm}$ ).

The mattresses were formed manually in a wooden frame $(400 \times 400 \mathrm{~mm})$ between two aluminum plates $(500 \times 500 \mathrm{~mm})$, pre-pressed at room temperature for five minutes at $0.5 \mathrm{MPa}$ and then hot-pressed for 10 minutes at $180{ }^{\circ} \mathrm{C}$ and $3.5 \mathrm{MPa}$. The panels were conditioned at $22 \pm 2{ }^{\circ} \mathrm{C}$ and $65 \pm 5 \%$ relative humidity for five days. Three panels were produced per treatment, totaling 12 experimental units.

\section{Rot-fungi test}

The panels' resistance against rot-fungi was assessed according to the standard AWPA E30 (2016) of the American Wood Protection Association. Two brown-rot Gloeophyllum trabeum $\approx$ Brunneoporus malicola (Berk. \& M.A. Curtis) (Mad 617) and Postia placenta $\approx$ Rhodonia placenta (Fr.) Niemelä, K.H. Larss. \& Schigel (Mad 698-R) were tested. Eight samples $(25 \times 25 \times 15.7 \mathrm{~mm})$ were tested by treatment and fungus, with $25 \times 25 \times 15.7 \mathrm{~mm}$. They were previously oven-dried at $103 \pm 2{ }^{\circ} \mathrm{C}$ for 48 hours (Mi: initial ovendried mass).

The glass flasks $(600 \mathrm{~mL})$ used in the experiment were filled with $300 \mathrm{~g}$ of red latosol (oxisol) from layer B, with a low amount of organic matter; a pH of 6.5 and $25 \%$ of waterretention capacity. Distilled water $(67 \mathrm{~mL})$ and two Pinus sp. wood feeder strips of $3.0 \times 2.80 \times 33.00 \mathrm{~mm}$ (thickness $\times$ width $\times$ length) were added to the flasks. The prepared flasks were sterilized in an autoclave at $121 \pm 2^{\circ} \mathrm{C}$ and $1.2 \mathrm{kPa}$ for $30 \mathrm{~min}$. After cooling, the flasks were stored in an incubation room $\left(27 \pm 1^{\circ} \mathrm{C}\right.$ and $\left.70 \pm 4 \% \mathrm{RH}\right)$. Six samples per treatment were used to control the operational mass loss.

The fungi were inoculated $\left(1.0 \mathrm{~cm}^{2}\right.$ inoculum) on the feeder strips in a laminar flow hood. After the inoculum colonized the soil (30 days), two particleboard samples were placed in each flask and the test was carried out for 12 weeks. After the test, the samples were removed from the flasks and carefully cleaned up with a brush, oven-dried at $103 \pm 2^{\circ} \mathrm{C}$ until constant mass (MO: oven-dried mass) and weighed. The mass loss was calculated [( $\mathrm{Mi}-\mathrm{M0}) / \mathrm{Mi} \times 100]$ and classified according to the standard E 30 (AWPA, 2016): i) highly resistant: 0-10\%; ii) resistant: $11-24 \%$; iii) slightly resistant: $25-44 \%$; iiii) non-resistant ( $\geq 45$ ). 


\section{Surface wettability test}

Wettability was measured by the static contact angle formed between distilled water and ethylene glycol and the surface of the samples using a goniometer. According to Walinder \& Johansson (2001), water works as a Lewis acid and ethylene glycol as a base.

Three samples of $25 \times 25 \times 15.7 \mathrm{~mm}$ by treatment were used, which were previously fixed on sandpaper (grit number 200) to improve the measurements. The equipment had a dosing syringe (100 $\mu \mathrm{L}$ capacity) adjusted to $4 \mu \mathrm{L}$-drops and the distance between the needle and the samples surface was $8 \mathrm{~mm}$. The software KSV Contact Angle Measurement System calculated the contact angle.

According to the recommendation of César (2011), the contact angle was measured twice by sample. Due to the accommodation of forces that occurs over time, an initial time (time 1) for drop deposition and a final time where the drop is already stabilized were considered. The measurements were made at the moment the drop touches the panel surface (initial time - 1 second) and after 30 seconds (final time - 30 seconds). The importance of measurements is due to the accommodation of forces that occurs over time. The results of graphs 1 and 2 show the initial and final time on the abscissa axis, while the ordinate axis shows the contact angles obtained in each treatment.

\section{Statistical analysis}

This work was assessed according to a completely randomized design, and the confidence level was 95\% for all tests. For the results of the chemical analysis, only two treatments were considered: untreated and leached particles. The means and standard deviations by treatment are presented.

The results of the fungi test and the wettability test were analyzed in a factorial arrangement, derived from the combination of the factors particles size $(0.50 \mathrm{~mm}$ and $0.85 \mathrm{~mm})$ and leaching in hot water (untreated and leached). The effect of the different fungi species (three) and solvents (two) were assessed individually. Two factors were considered: particle size and two situations (treated and untreated). In cases where there was no significant interaction between the factors, they were studied separately.

Before the variation analysis (ANOVA), The Lilliefors test was used to check the normality of the data and the Cochran test checked the homogeneity of variances were performed. The Tukey multiple ranges test was applied in cases of significant difference among treatments.

\section{RESULTS AND DISCUSSION}

\section{Chemical composition}

Table 1 shows the results and variations which were found between the treatments. The contents of holocellulose and lignin increased after leaching, respectively by 4.53 percentage points (p.p.) and 0.93 p.p. The total extractives and ashes were reduced after leaching respectively in 2.14 p.p. and 0.85 p.p.

Table 1. Results (averages) of chemical analysis by treatment.

\begin{tabular}{|c|c|c|c|c|c|c|}
\hline \multirow{2}{*}{ Treatments } & \multirow{2}{*}{$\begin{array}{c}\text { Holocelulose } \\
\text { (\%) }\end{array}$} & \multicolumn{3}{|c|}{ Lignin (\%) } & \multirow{2}{*}{$\begin{array}{l}\text { Total } \\
\text { extractives } \\
\text { content } \\
(\%)\end{array}$} & \multirow{2}{*}{$\begin{array}{c}\text { Ash } \\
\text { content } \\
(\%)\end{array}$} \\
\hline & & Soluble & Insoluble & Total & & \\
\hline Untreated & $62.35(4.33)$ & $0.61(0.04)$ & $22.21(2.40)$ & $22.82(2.36)$ & $10.06(1.13)$ & $2.30(0.39)$ \\
\hline Leached & $66.88(2.77)$ & $0.71(0.09)$ & $23.04(2.54)$ & $23.75(2.61)$ & $7.92(0.18)$ & $1.45(0.47)$ \\
\hline
\end{tabular}

Standard deviation in parentheses.

The holocellulose content of the control particles was similar to that found by (Brito et al., 2020), who obtained $68.11 \%$ and higher than that obtained by (Brito et al., 1987); a value of $63.7 \%$, for the $D$. giganteus polysaccharide fraction. For lignin content, particles treated in hot 
water (T2), showed higher averages (Table 1). The total lignin value was lower than that reported by (Marinho et al., 2012), who obtained $24.11 \%$ for adult $D$. giganteus.

Lignin can have an adhesive function, being desirable in the production of particleboards (Bufalino et al., 2012b), for influencing wettability and for having positive effects on biological resistance. It is not possible to state exactly the cause of the increase in the levels of holocellulose and lignin in the treated particles, since the temperature used in the treatment of the particles would not be able to cause significant changes in the material structure. There was probably a dissociation of the extractives, mainly sugars, which may have been accounted for as an apparent increase in the content of holocellulose and lignin after the treatment of the particles.

The content of totals extractives obtained in this research for the control particles was higher than that reported by Brito et al. (2020), for the D. giganteus, which found a value of 6.30\%. Parameters related to age (Kumar et al., 1994), edaphic-climatic conditions and species can influence the percentage of total extracts existing in bamboo. For D. giganteus, the levels of total extractives obtained by Marinho et al. (2012), ranged from 7.87 (culms with 2 years old) to $10.27 \%$ (culms with 6 years old). The value obtained in the present research was intermediate to those cited by the authors.

Based on the values obtained in this research, there was a leaching of the extractives present in the particles submitted to the treatment in hot water, since the average percentage was reduced, compared to the control particles. According to Oliveira et al. (2005), hot water extracts components such as tannins, sugars, dyes and starch. Therefore, some of these substances may have been eliminated during treatment and afterwards with the exposure of the particles in running water. The importance of the extractives content is related to the particle adhesion process that can be impaired (Bufalino et al., 2012a), but, on the other hand, they can contribute to increase or reduce the resistance of the chipboard depending on the type of biological agent.

The same reduction trend was observed for the ash content in the particles treated in hot water (Table 1) in relation to the control. After treatment it was noted that the inorganic material has been reduced. The value obtained in both treatments (Table 1) was higher than the value of $0.64 \%$ obtained by Marinho et al. (2012).

\section{Resistance against rot-fungi}

The results of mass loss by treatment and fungus are presented in Table 2. According to the mass loss criterion (AWPA, 2016), all treatments were "highly resistant" to the attack of R. placenta. Regarding B. malicola attack, treatments T1 and T3 were also "highly resistant" and treatments T2 and T4 were "resistant". Regarding $T$. versicolor attack, treatment T1 and T3 were "slightly resistant" and T2 and T4 were "resistant".

Table 2. Results of fungi-test by treatment: averages of mass loss and its classification according to the fungus

\begin{tabular}{|c|c|c|c|c|c|c|}
\hline \multirow[b]{2}{*}{ Treatments } & \multicolumn{2}{|c|}{ R. placenta * } & \multicolumn{2}{|c|}{ B. malicola ** } & \multicolumn{2}{|c|}{ T. versicolor ** } \\
\hline & $\begin{array}{c}\text { Mass } \\
\text { Loss (\%) }\end{array}$ & $\begin{array}{c}\text { Class of } \\
\text { Resistant }\end{array}$ & $\begin{array}{c}\text { Mass Loss } \\
(\%)\end{array}$ & $\begin{array}{l}\text { Class of } \\
\text { Resistant }\end{array}$ & $\begin{array}{c}\text { Mass Loss } \\
(\%)\end{array}$ & $\begin{array}{l}\text { Class of } \\
\text { Resistant }\end{array}$ \\
\hline Untreated/0.50mm & $2.48(0.04)$ & $\begin{array}{l}\text { Higly } \\
\text { resistant }\end{array}$ & $8.29(0.95)$ & $\begin{array}{l}\text { Higly } \\
\text { resistant }\end{array}$ & $25.66(1.92)$ & $\begin{array}{l}\text { Slightly } \\
\text { resistant }\end{array}$ \\
\hline Leached/0.50mm & $2.76(0.09)$ & $\begin{array}{l}\text { Higly } \\
\text { resistant }\end{array}$ & $18.25(1.38)$ & Resistant & $19.25(1.54)$ & Resistant \\
\hline Untreated $/ 0.85 \mathrm{~mm}$ & $2.76(0.05)$ & $\begin{array}{l}\text { Higly } \\
\text { resistant }\end{array}$ & $8.60(1.82)$ & $\begin{array}{l}\text { Higly } \\
\text { resistant }\end{array}$ & 26.67 (2.09) & $\begin{array}{l}\text { Slightly } \\
\text { resistant }\end{array}$ \\
\hline Leached/0.50 mm & $2.79(0.04)$ & $\begin{array}{l}\text { Higly } \\
\text { resistant }\end{array}$ & $19.63(2.64)$ & Resistant & 20.35 (1.67) & Resistant \\
\hline
\end{tabular}

Note: * Not significant and ** significant by F test $(\mathrm{p}>0.05)$. ('Weight loss (\%); Standard deviation in parentheses. 
According to the ANOVA, the tested factors were not significant $(p>0.05)$ for $R$. placenta

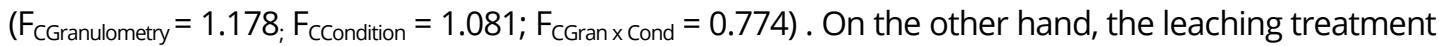

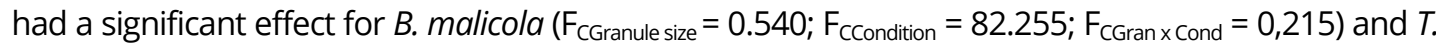

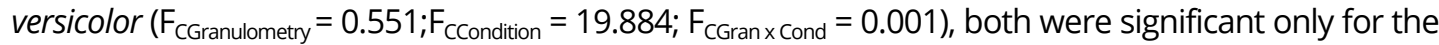
condition factor. Table 3 shows the results of the further analysis considering only the factor leaching.

Table 3. Mass loss caused by B. malicola and T. versicolor as a function of leaching

\begin{tabular}{ccc}
\hline & \multicolumn{3}{c}{ Mass loss (\%) } \\
\cline { 2 - 3 } Treatment & B. malicola & T. versicolor \\
\hline Untreated & $8.44 \mathrm{~b}(1.40)$ & $26.16 \mathrm{a}(3.59)$ \\
Leached & $18.94 \mathrm{a}(2.46)$ & $19.80 \mathrm{~b}(2.71)$ \\
\hline
\end{tabular}

Averages followed by the same letter in the column do not differ significantly according to the Tukey test $(p>0.05)$; Standard deviation in parentheses.

The extractives can be toxic to certain rot-fungi and decrease natural durability (Eaton \& Hale, 1993). On the other hand, when constituted by starch and other hot-water soluble sugars, they may promote a fungal attack. Based on these statements, the difference between the attack rates of brown rot fungi, $R$. placenta and B. malicola, can be explained according to the presence and types of extractives present in the samples, which has the ability to inhibit or accentuate fungal attack. The attack rate of $B$. malicola was higher in panels made of treated particles. Probably with the immersion of the particles in hot water, some types of extractives were removed, which favored the attack of this rotting fungus.

The effect of leaching intensified the attack of $B$. malicola (brown-rot) and reduced that of T. versicolor (white-rot). It was observed that the white rot fungus caused greater loss of mass. Numerically, the reduction in the levels of extractives and mineral substances and the increase in the levels of holocellulose and lignin (Table 1) inhibited the attack of the fungus T. versicolor which caused less loss of mass of the panels made with treated particles. In contrast, $B$. malicola caused greater mass losses in panels made up of treated particles. Probably there was a removal of some type of extract that facilitated the attack of the fungus. In addition, white rot fungi are characterized by indistinctly deteriorating all major chemical constituents (cellulose, hemicelluloses and lignin), while brown rot fungi strictly attack polysaccharides (Stangerlin et al., 2011).

\section{Wettability test}

According to the ANOVA, the tested factors were not significant $(p>0.05)$ for ethylene glycol

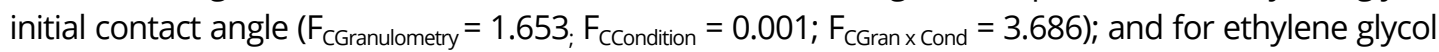
last contact angle $\left(\mathrm{F}_{\mathrm{CG} \text { ranulometry }}=0.169 ; \mathrm{F}_{\mathrm{CC} \text { Condition }}=0.001 ; \mathrm{F}_{\mathrm{CGran}} \times\right.$ Cond $\left.=1.566\right)$. However, a significant difference was observed for water among the particle size and interaction among the factors for the initial contact angle. The interaction was extended and the effect of the angle was evaluated (Table 4). For water initial contact angle measurement was used $\left(F_{\text {CGranulometry }}=28.729\right.$; $F_{\text {cCondition }}=1.901$; $F_{C G r a n} \times$ Cond $\left.=17.737\right)$. The variance analysis showed a statistical difference between the granule size effects and particle condition for the final contact angle ${ }^{\circ}$. For water last contact the angle

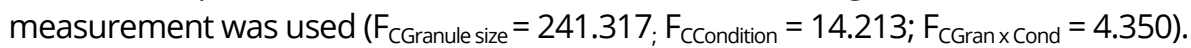

Table 4. Averages of initial and final contact angles for water and ethylene glycol.

\begin{tabular}{cccccc}
\hline \multirow{2}{*}{ Treatments } & \multicolumn{2}{c}{ Water } & & \multicolumn{2}{c}{ Ethylene glycol } \\
\cline { 2 - 3 } \cline { 5 - 6 } & (Initial) & (Final) & & (Initial)* & (Final)* $^{*}$ \\
\hline Untreated/0.50mm & $116.52(10.08)$ & $116.52(11.73)$ & & $103.92(12.84)$ & $67.42(13.64)$ \\
Leached/0.50mm & $126.19(12.53)$ & $126.19(15.83)$ & & $94.99(11.75)$ & $57.35(10.53)$ \\
Untreated/0.85mm & $114.53(17.73)$ & $114.53(10.98)$ & & $100.91(14.82)$ & $60.53(11.93)$ \\
Leached/0.85mm & $109.63(18.64)$ & $109.63(10.03)$ & & $110.20(9.85)$ & $70.97(8.96)$ \\
\hline
\end{tabular}

Note: * Not significant and ** significant by F test $(\mathrm{p}>0.05)$; Standard deviation in parentheses. 
The initial contact angle for both water and ethylene glycol were higher than $90^{\circ}$, which characterizes the panels' surface as "not wetting" according to Myers (1999). Regarding the final contact angle, the surfaces can be classified as "partially wetting" for both solvents, since the results ranged from $30^{\circ}$ to $89^{\circ}$.

For untreated particles, there was no significant difference in initial contact angles according to the size of particles. However, the opposite was found for the leached particles, with higher average for $0.50 \mathrm{~mm}$ than for $0.85 \mathrm{~mm}$. Smaller particles have more contact among themselves, leading to better compaction and smoother surfaces. This results in higher contact angles, which means lower wettability.

For $0.50 \mathrm{~mm}$ particles, there was no effect of leaching, on the initial contact angles. Nevertheless, the opposite was found for $0.85 \mathrm{~mm}$, with higher average for untreated particles (Table 5). Leached particles of $0.85 \mathrm{~mm}$ gave the best result, because this combination resulted in smaller initial contact angle, meaning best interaction between particles and liquids. However, this may cause larger translocation of the rot-fungi enzymes and negatively influence the panels' resistance.

Table 5. Interaction between the factors leaching and particles size: averages of contact angle with water

\begin{tabular}{ccc}
\hline \multirow{2}{*}{ Particle Size $(\mathbf{m m})$} & Untreated & Contact angle $\left(^{\circ}\right)$ \\
\cline { 2 - 3 } & $116.52 \mathrm{aB}$ & $126.19 \mathrm{aA}$ \\
0.50 & $114.53 \mathrm{aA}$ & $109.63 \mathrm{bA}$ \\
\hline
\end{tabular}

Averages followed by the same uppercase letter in the horizontal or lowercase in the vertical, do not differ statistically by the Tukey test $(p>0.05)$.

According to the results presented in Table 6, the final contact angle was smaller for $0.50 \mathrm{~mm}$ panels, probably due to the higher density of their external layer, capillarity, and water adsorption. Such particleboards have a larger specific superficial surface area, hence, larger quantities of sorption sites and a stronger affinity with water, which might have yielded the narrower contact angle formed and higher wettability on their surface. On the other hand, their biological resistance may have been negatively affected.

Table 6. Averages of final contact angle with water: analysis of factors separately

\begin{tabular}{cccc}
\hline Particles size & Contact angle $\left(^{\circ}\right)$ & Leaching & Contact angle $\left(^{\circ}\right)$ \\
\hline $0.50 \mathrm{~mm}$ & $49.91 \mathrm{~b}(3.75)$ & Untreated & $63.57 \mathrm{~b}(9.23)$ \\
$0.85 \mathrm{~mm}$ & $85.97 \mathrm{a} \mathrm{(3.12)}$ & Leached & $72.32 \mathrm{a} \mathrm{(8.72)}$ \\
\hline
\end{tabular}

Averages followed by the same letter in the column do not differ significantly according to the Tukey test $(p>0.05)$; Standard deviation in parentheses.

Panels made with untreated particles had smaller final contact angle. Probably some extractives present in the particles may have migrated to the surface after the treatment, which would cause the water drop to repel and prevent it from spreading over the surface of the panel, explaining the less wettability (greater contact angle). In addition, some physical factors previously mentioned, such as that of treated particles' stronger consolidation, may have contributed in a higher balance of the droplet. Figures 1 and 2 show changes in contact angle in function of time. 

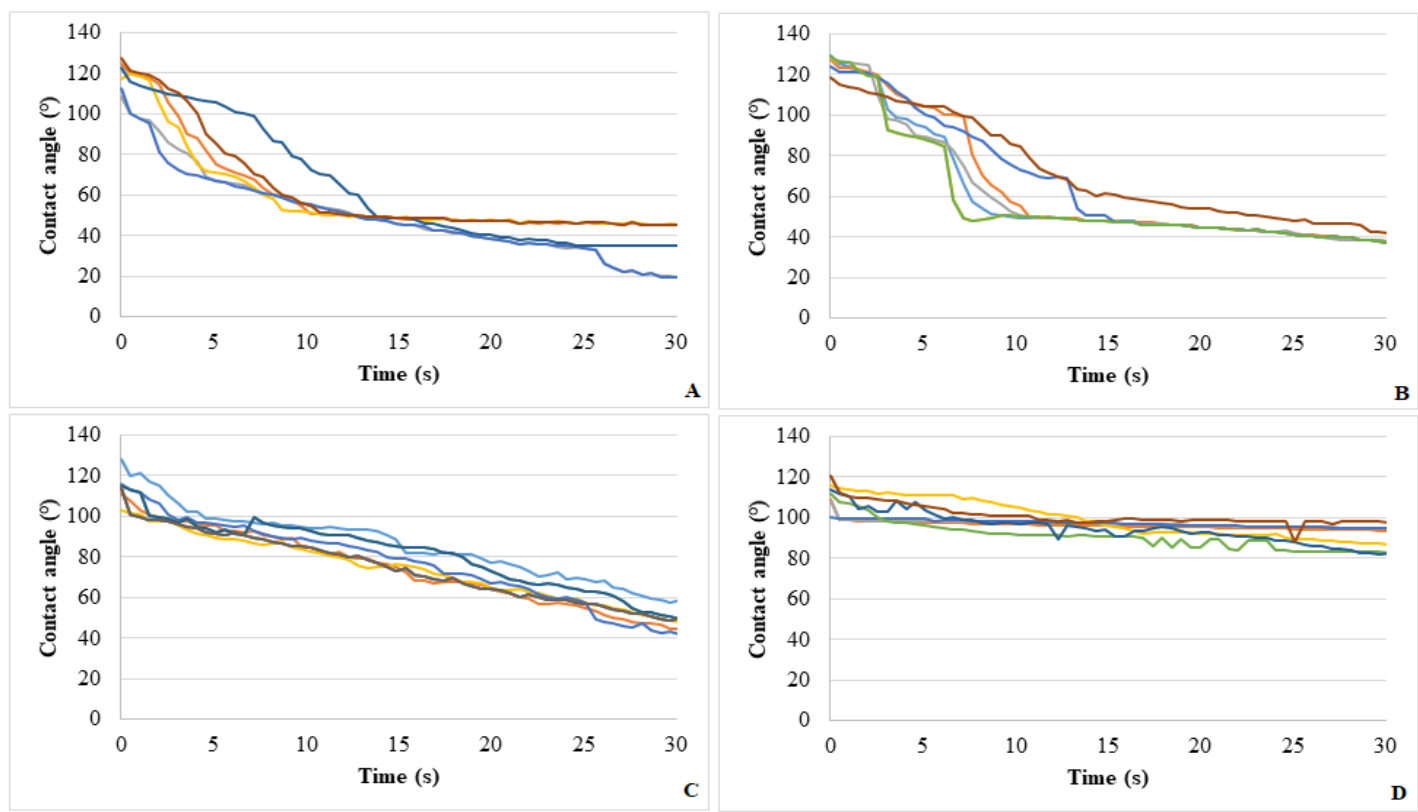

Figure 1. Contact angles with water over time: (A) $0.50 \mathrm{~mm} / \mathrm{untreated}$; (B) $0.50 \mathrm{~mm} / \mathrm{leached}$;

(C) $0.85 \mathrm{~mm} /$ untreated; (D) $0.85 \mathrm{~mm} /$ leached.
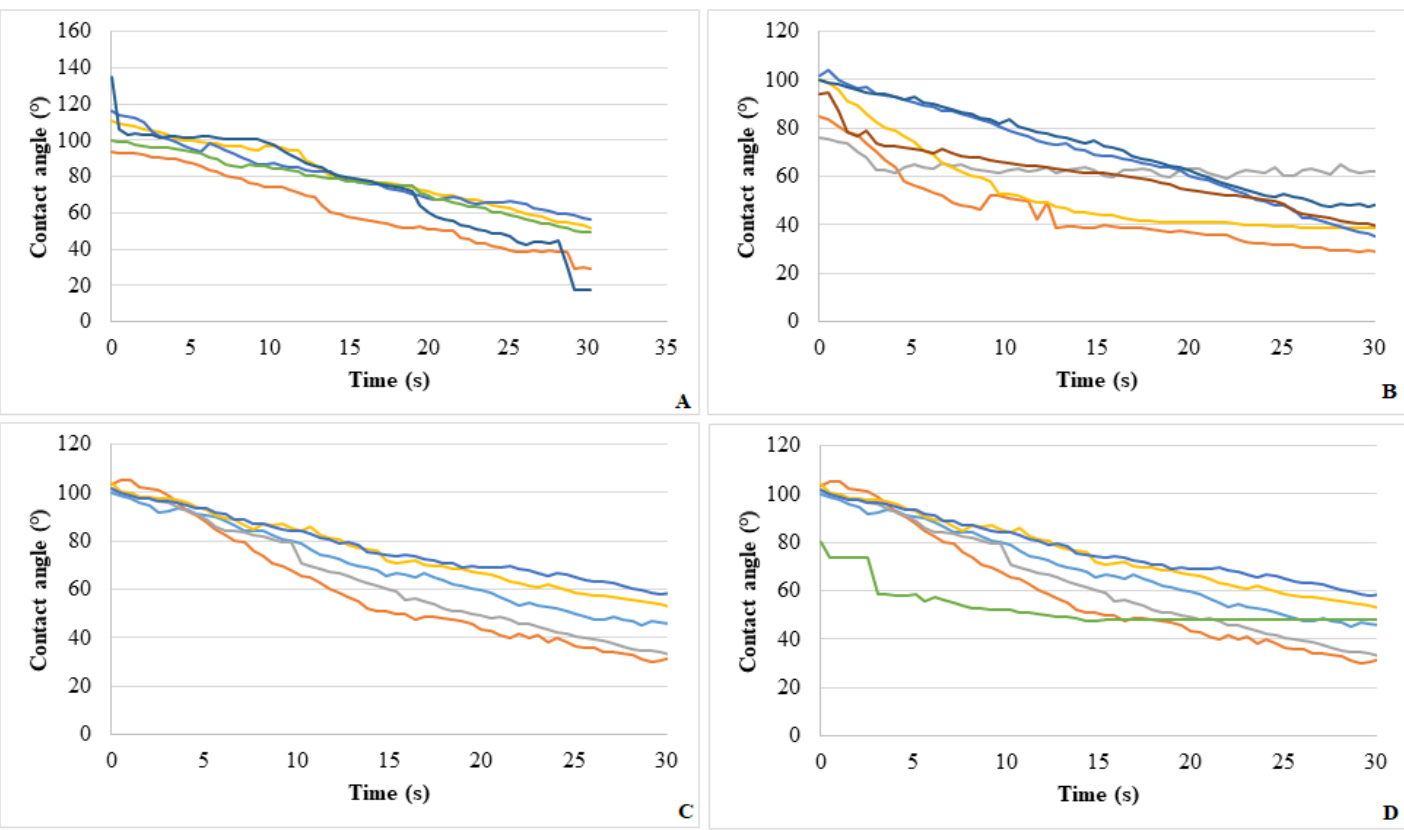

Figure 2. Contact angles with ethylene glycol over time: (A) $0.50 \mathrm{~mm} / \mathrm{untreated}$; (B) $0.50 \mathrm{~mm} / \mathrm{leached}$; (C) $0.85 \mathrm{~mm} /$ untreated; (D) $0.85 \mathrm{~mm} /$ leached.

The slopes of the contact angles between water and the surfaces had similar behavior, except for leached particles with $0.85 \mathrm{~mm}$ (Figure 1D), which showed smaller range (flatter slope) along time. The decrease in the curves resulted from the porous surface of the bamboo particleboards, which facilitated the solvent absorption.

For ethylene glycol (Figure 2) the slopes had similar behavior as water (Figure 1), concerning the steep decreasing contact angles along time. Therefore, for both solvents, the contact angles decreased along time, meaning higher wettability. 


\section{CONCLUSIONS}

Leaching the particles with hot water reduced the contents of total extractives and ash, which led to increased resistance against Trametes versicolor (white-rot fungus). On the other hand, the resistance against $B$. malicola (brown-rot) was reduced. No significant effect was verified for R. placenta (brown-rot).

Leaching and particle size influenced the contact angle between water and the surface of the panels, demonstrating that extractives and particle geometry can influence the application of finishing products on bamboo panel surfaces.

\section{REFERENCES}

Abdulkareem, S. A., \& Adeniyi, A. G. (2017). Production of particleboards using polystyrene and bamboo wastes. Nigerian Journal of Technology, 36(3), 788-793.

Almeida, A. C., Araujo, V. A., Morales, E. A. M., Gava, M., Munis, R. A., Garcia, J. N., \& Barbosa, J. C. (2017). Wood bamboo particleboard: mechanical properties. BioResources, 12(4), 7784-7792.

American Wood Protection Association - AWPA. (2016). E-30: standard method for evaluating natural decay resistance of woods using laboratory decay tests (pp. 494-498). Birmingham: AWPA.

Amiandamhen, S., \& Izekor, D. N. (2013). Effect of wood particle geometry and pre-treatments on the strength and sorption properties of cement-bonded particleboards. Journal of Applied and Natural Science, 5(2), 318-322.

Arruda, L. M., Del Menezzi, C. H. S., Teixeira, D. E., \& Araújo, P. C. (2011). Lignocellulosic composites from Brazilian giant bamboo (Guadua magna) Part 1: properties of resin bonded particleboards. Maderas. Ciencia y Tecnología, 13(1), 49-58.

Baharoğlu, M., Nemli, G., Sari, B., Bardak, S., \& Ayrilmiş, N. (2012). The influence of moisture content of raw material on the physical and mechanical properties, surface roughness, wettability, and formaldehyde emission of particleboard composite. Composites. Part B, Engineering, 43(5), 2448-2451.

Bazzetto, J. T. L., Bortoletto Junior, G., \& Brito, F. M. S. (2019). Effect of particle size on bamboo particle board properties. Floresta e Ambiente, 26(2), e20170125.

Belini, U. L., Leite, M. K., Tomazello Filho, M., Chaix, G., Baudasse, C., Lemenager, N., \& Thevenon, M. F. (2014). Bioensaios em painéis confeccionados com eucalipto e bagaço de cana-de-açúcar. Revista Árvore, 38(2), 361-368.

Brito, F. M. S., Paes, J. B., Oliveira, J. T. S., Arantes, M. D. C., \& Dudecki, L. (2020). Chemical characterization and biological resistance of thermally treated bamboo. Construction \& Building Materials, 262, 120033.

Brito, F. M. S., Paes, J. B., Oliveira, J. T. S., Arantes, M. D. C., Vidaurre, G. B., \& Brocco, V. F. (2018). Physicomechanical characterization of heat-treated glued laminated bamboo. Construction \& Building Materials, 190, 719-727.

Brito, J. O., Tomazello Filho, M., \& Salgado, A. L. B. (1987). Produção e caracterização do carvão vegetal de espécies e variedades de bambu. IPEF, (36), 13-17.

Bufalino, L., Abino, V. C. S., Sá, V. A., Correa, A. A. R., Mendes, L. M., \& Almeida, N. A. (2012a). Particleboards made from Australian red cedar: processing variables and evaluation of mixed species. Journal of Tropical Forest Science, 24(2), 162-172.

Bufalino, L., Protásio, T. P., Couto, A. M., Nassur, O. A. C., Sá, V. A., Trugilho, P. F., \& Mendes, L. M. (2012b). Caracterização química e energética para aproveitamento da madeira de costaneira e desbaste de cedro australiano. Pesquisa Florestal Brasileira, 32(70), 129-137.

Calegari, L., Haselein, C. R., Scaravelli, T. L., Santini, E. J., Stangerlin, D. M., \& Gatto, D. A. (2007). Desempenho físico-mecânico de painéis fabricados com bambu (Bambusa vulgaris Schr.) em combinação com madeira. Cerne, 13(1), 57-63.

Calegari, L., Haselein, C. R., Barros, M. V., Scaravelli, T. L., Dacosta, L. P. E., Pedrazzi, C., \& Hillig, E. (2004). Adição de aparas de papel reciclável na fabricação de chapas de madeira aglomerada. Ciência Florestal, 14(1), 193-204.

César, A. A. S. (2011). Estudo da interação adesivo-partícula em painéis OSB (Oriented Strand Board) (Dissertação de mestrado). Universidade Federal de Lavras, Lavras.

Chong, J., \& Yang, Z. (2010). Surface wettability of rice straw particle board. Journal of North West Forestry University, v. 5. 
Cruz, M. P., Barbosa, L. C. A., Maltha, C. R. A., Gomide, J. L., \& Milanez, A. F. (2006). Caracterização química do "pitch" em indústria de celulose e papel de Eucalyptus. Química Nova, 29(3), 459-466.

Dinhane, F. C. R., Araújo, I. I., Valarelli, I. D., Bueno, M. A. P., Ferreira, B. S., \& Campos, C. I. (2015). Particleboard manufactured with bamboo and coconut fibers in different ratios of adhesive. Advanced Materials Research, 1088, 672-675.

Eaton, R. A., \& Hale, M. D. C. (1993). Wood: decay, pests and protection (546 p.). London: Chapman \& Hall.

Ferreira, L. M. V. (2013). Revestimentos hidrofóbicos (Dissertação de mestrado). Faculdade de Ciências e Tecnologias, Universidade Nova de Lisboa, Lisboa.

Filgueiras, T. S., \& Viana, P. L. (2017). Bambus brasileiros: morfologia, taxonomia, distribuição e conservação. In P. M. Drumond \& G. Wiedman (Eds.), Bambus no Brasil: da biologia à tecnologia (1. ed., pp. 16-27). Rio de Janeiro: ICH.

Gonçalves, F. G., Brocco, V. F., Paes, J. B., Loiola, P. L., \& Lelis, R. C. C. (2014). Resistência de painéis aglomerados de Acacia mangium Willd. colados com ureia-formaldeído e taninos a organismos xilófagos. Floresta e Ambiente, 21(3), 409-415.

Guilherme, D. O., Ribeiro, N. P., \& Cereda, M. P. (2017). Cultivo, manejo e colheita do bambu. In P. M. Drumond \& G. Wiedman (Eds.), Bambus no Brasil: da biologia à tecnologia (1. ed., pp. 28-42). Rio de Janeiro: $\mathrm{ICH}$.

Haselein, C. R., Calegari, L., Barros, M. V., Hack, C., Hillig, E., Pauleski, D. T., \& Pozzera, F. (2002). Resistência mecânica e à umidade de painéis aglomerados com partículas de madeiras de diferentes dimensões. Ciência Florestal, 12(2), 127-134.

Iwakiri, S. (2005). Painéis de madeira reconstituída (247p.). Curitiba: FUPEF.

Iwakiri, S., \& Prata, J. G. (2008). Utilização da madeira de Eucalyptus grandis e Eucalyptus dunnii na produção de painéis de cimento-madeira. Cerne, 14(1), 68-74.

Iwakiri, S., Trianoski, R., Weber, A. M., Bonfatti Junior, E. A., Pereira, G. F., Bueno, J. A., Cechin, L., \& Raia, R. Z. (2017). Efeitos do tratamento de partículas e aceleradores de endurecimento na produção de painéis cimento-madeira de Hevea brasiliensis. Floresta, 47(3), 289-296.

José, F. J., \& Beraldo, A. L. (2010). Tableros de partículas de bambú (Bambusa vulgaris Schrad) y resina poliuretana a base de aceite de rícino (Ricinus communis L.). Ambiente Construído, 10(4), 259-266.

Kumar, S., Shukla, K. S., Tndra, D. T., \& Dobriyal, P. B. (1994). Bamboo preservation techniques: a review (INBAR. Technical Report, No. 3). Dehra Dun: New Delhi and ICFRE.

Lima Júnior, H. C., \& Dias, A. A. (2001). Vigas mistas de madeira de reflorestamento e bambú laminado colado: análise teórica e experimental. Revista Brasileira de Engenharia Agrícola e Ambiental, 5(3), 519-524.

Maloney, T. M. (1977). Modern particleboard \& dry-process fiberboard manufacturing (672 p.). San Francisco: Miller Freeman.

Marinho, N. P., Nisgoski, S., Klock, U., Andrade, A. S., \& Muñiz, G. I. B. (2012). Análise química do bambugigante (Dendrocalamus giganteus wall. ex munro) em diferentes idades. Ciência Florestal, 22(2), 417-422.

Marinho, N. P., Nascimento, E. M., Nisgoski, S., \& Valarelli, I. D. (2013). Some physical and mechanical properties of medium density fiberboard made from giant bamboo. Materials Research, 16(6), 1387-1392.

Marra, A. A. (1992). Technology of wood bonding: principles in practice (454 p.). New York: Van Nostrand Reinhold.

Melo, R. R., \& Del Menezzi, C. H. S. (2010). Influência da massa específica nas propriedades físicomecânicas de painéis aglomerados. Silva Lusitana, 18(1), 59-73.

Melo, R. R., Stangerlin, D. M., Sousa, A. P., Cademartori, P. H. G., \& Schneid, E. (2015a). Propriedades físico-mecânicas de painéis aglomerados madeira-bambu. Ciência Rural, 45(1), 35-42.

Melo, R. R., Stangerlin, D. M., Santana, R. R. C., \& Pedrosa, T. D. (2015b). Decay and termite resistance of particleboard manufactured from wood, bamboo and rice husk. Maderas. Ciencia y Tecnología, 17(1), 55-62.

Morais, W. W. C., Haselein, C. R., Susin, F., Vivian, M. A., \& Souza, J. T. (2018). Use of Bambusa tuldoides and Eucalyptus grandis for manufacturing particleboards. Ciência Florestal, 28(2), 746-757.

Moslemi, A. A. (1974). Particleboard (Vol. 1, 244 p.). London: Southern Illinois University Press.

Myers, D. (1999). Surface, interfaces, and colloids (519 p.). New York: VCH Publishers.

Nascimento, E. C. (2020). Avaliação do ciclo de vida. Recuperado em 1 de março de 2020, de https://materioteca.paginas.ufsc.br/bambu/bambu-ciclo-de-vida/ 
Nurhazwani, O., Jawaid, M., Paridah, M. T., Abdul, J. H., \& Hamid, S. A. (2016). Hybrid particleboard from bamboo (Dendrocalamus asper) veneer waste and rubberwood (Hevea brasileinesis). BioResources, 11(1), 306-323.

Oliveira, C. R. F., Faroni, L. R., Guedes, R. N. C., Pallini, A., \& Gonçalves, J. R. (2002). Parasitismo de Acarophenax lacunatus (Cross \& Krantz) (Prostigmata: Acarophenacidae) sobre Dinoderus minutus (Fabr.) (Coleoptera: Bostrichidae). Neotropical Entomology, 31(2), 245-248.

Oliveira, J. T. S., Souza, L. C., Della Lucia, R. M., \& Souza Júnior, W. P. (2005). Influência dos extrativos na resistência ao apodrecimento de seis espécies de madeira. Revista Árvore, 29(5), 819-826.

Razera, D. L. (2006). Estudo sobre as interações entre as variáveis do processo de produção de painéis aglomerados e produtos moldados de madeira (Tese de doutorado). Universidade Federal do Paraná, Curitiba.

Reinprecht, L., Iždinský, J., \& Vidholdová, Z. (2018). Biological resistance and application properties of particleboards containing nano-zinc oxide. Advances in Materials Science and Engineering, 2018(1), 1-8.

Sá, V. A., Bufalino, L., Albino, V. C. S., Corrêa, A. A., Mendes, L. M., \& Almeida, N. A. (2012). Mistura de três espécies de reflorestamento na produção de painéis cimento-madeira. Revista Árvore, 36(3), 549-557.

Stangerlin, D. M., Melo, R. R., Garlet, A., \& Gatto, D. A. (2011). Durabilidade natural de painéis aglomerados confeccionados com Eucalyptus grandis e Bambusa vulgaris em ensaio de apodrecimento acelerado. Ciência Rural, 41(8), 1369-1374.

Technical Association of the Pulp and Paper Industry - TAPPI. (1997). Test methods T $204 \mathrm{~cm}$-97: solvent extractives of wood and pulp (4 p.). Atlanta: TAPPI Techonology Park.

Technical Association of the Pulp and Paper Industry - TAPPI. (1999). Test methods T $207 \mathrm{~cm}$-99: Water solubility of wood and pulp (3 p.). Atlanta: TAPPI Techonology Park.

Technical Association of the Pulp and Paper Industry - TAPPI. (2002a). Test methods T 222 om-02: acid insolub lignin in wood and pulp (5 p.). Atlanta: TAPPI Techonology Park.

Technical Association of the Pulp and Paper Industry - TAPPI. (2002b). Test methods T 211 om-02: ash in wood, pulp, paper and paperboard: combustion at $525^{\circ} \mathrm{C}$ (5 p.). Atlanta: TAPPI Techonology Park.

Teixeira, D. E., Alencar, G., \& Sanches, K. L. (2009). Resistance of particleboard panels made of agricultural residues and bonded with synthetic resins or PVC plastic to wood-rotting fungi. Cerne, 15(4), 413-420.

Tombolato, A. F. C., Greco, T. M., \& Pinto, M. M. (2012). Dez espécies de bambus exóticos mais comuns no paisagismo no Brasil. Revista Brasileira de Horticultura Ornamental, 18(2), 105-114.

Vital, B. R., Andrade, P. I. L., Carneiro, A. C. O., Cabral, C. P. T., \& Carvalho, A. M. M. (2014). Estabilidade dimensional e resistência à tração perpendicular de painéis fabricados com partículas termorretificadas oriundas de embalagens de Pinus sp. Revista Árvore, 38(5), 951-959.

Walinder, M. E. P., \& Johansson, I. (2001). Measurement of wood wettability by the Wilhelmy method. Holzforschung, 55(1), 21-32.

Yingprasert, W., Matan, N., Chaowana, P., \& Matan, N. (2015). Fungal resistance and physico-mechanical properties of cinnamon oil- and clove oil-treated rubberwood particleboards. Journal of Tropical Forest Science, 27(1), 69-79.

Zaia, U. J., Cortez-Barbosa, J., Martines Morales, E. A., Lahr, F. A. R., Nascimento, M. F., \& Araujo, V. A. (2015). Production of particleboards with bamboo (Dendrocalamus giganteus) reinforcement. BioResources, 10(1), 1424-1433.

Authors' contributions: FMSB: Data curation, formal analysis, investigation, methodology, project adminisitration, validation, visualization, writing - original draft, writing - review \& editing. GBJ: conceptualization, project adminisitration, resources, supervision. JBP: investigation, methodology, resources, supervision, writing review \& editing 